\title{
Paying for avoided deforestation in the Brazilian Amazon: from cost assessment to scheme design
}

\author{
J. BÖRNER ${ }^{1}$ and S. WUNDER ${ }^{2}$ \\ ${ }^{1}$ Amazon Initiative \& International Centre for Tropical Agriculture, CIAT, clo Embrapa, Tr. E. Pinheiro s/n, Belém-PA, Brazil \\ ${ }^{2}$ Center for International Forestry Research, CIFOR, c/o Embrapa, Tr. E. Pinheiro s/n, Belém-PA, Brazil
}

Email: j.boerner@cgiar.org and s.wunder@cgiar.org

\begin{abstract}
SUMMARY
Reducing emissions from deforestation and degradation (REDD) is considered a significant mitigation opportunity. Forest loss in the Brazilian Amazon has traditionally been highest in the world and, thus, represents a likely target for future REDD initiatives. The paper presents an ex-ante assessment of the potential REDD costs in two of the three largest states in the Brazilian Amazon using official land use and cover change statistics. The two states, Mato Grosso and Amazonas, historically feature largely different land use dynamics. The findings focus on the opportunity costs of REDD and suggest that at least 1 million ha of projected deforestation in Mato Grosso and Amazonas could be compensated for at current carbon prices until 2017. Total costs may differ between US\$ 330 million and over US\$ 1 billion depending on how payment mechanisms are designed. Implications of payment scheme design for the political economy of REDD are discussed.
\end{abstract}

Keywords: opportunity costs, REDD, payments for environmental services, carbon supply, land use

Coûts pour éviter la déforestation dans l'Amazonie brésilienne: de l'évaluation des coûts à la conception de projet

\section{J. BÖRNER et S. WUNDER}

La réduction des émissions provenant de la dégradation et de la déforestation (REDD) est considérée comme une opportunité d'atténuation importante. La perte de la forêt en Amazonie a été traditionnellement la plus grande au monde, et représente par conséquent un but probable pour les futures initiatives de la REDD. L'article présente un évaluation ex-ante des coûts potentiels de la REDD dans deux des trois états les plus importants dans l'Amazonie brésilienne en utilisant les statistiques officielles de l'utilisation de la terre et celles des changements du couvert forestier. Les deux états en question, le Matto Grosso et l'Amazonas, connaissent une historique bien différente de dynamique de l'utilisation de la terre. Les résultats se concentrent sur l'opportunité des coûts de la REDD et suggèrrent qu'au moins 1 million d'ha de déforestation prévue dans le Matto Grosso et l'Amazonas pourraient être compensés aux prix actuels du carbone jusqu'en 2017. Le coût total pourrait aller de 330 millions de dollars US à plus d'1 million de dollars US, selon la manière dont les mécanismes de paiement sont conçus. Les implications de la conception des mécanismes de paiement pour l'économie politique de la REDD sont examinées.

\section{Los pagos para evitar la deforestación en la Amazonia brasileña: desde una evaluación de costos hacia el diseño de planes}

\section{J. BÖRNER y S. WUNDER}

La Reducción de Emisiones por Deforestación y Degradación (REDD) se considera una oportunidad importante para aliviar los efectos de la deforestación. La tasa de pérdida de cobertura forestal en la Amazonia brasileña ha sido tradicionalmente la más alta del mundo, y por eso representa un objetivo probable para iniciativas futuras de REDD. El estudio presenta una evaluación preliminar de los costos potenciales de la REDD en dos de los tres mayores estados de la Amazonia brasileña, y se basa en las estadísticas oficiales del uso de la tierra y del cambio en cobertura forestal. Los dos estados, Mato Grosso y Amazonas, demuestran dinámicas históricas del uso de la tierra bastante diferentes. Las conclusiones se centran en los costos de oportunidad de REDD y sugieren que un mínimo de un millón de hectáreas de deforestación prevista podría ser indemnizado hasta 2017 al precio actual del carbono. Los costos globales podrían oscilar entre US\$330 millones y más de mil millones, según la forma de diseñar los mecanismos de pago. Se analizan las implicaciones para la economía política del diseño del plan de pago de REDD. 


\section{DOES REDD MAKE SENSE IN THE AMAZON REGION?}

Both the International Panel on Climate Change (IPCC) and the Stern Review on the Economics of Climate Change reckon that avoiding deforestation accounts for a significant share of the global potential for climate change mitigation through forest related activities (IPCC 2007, Stern 2007). For many years, Brazil has been the single country with the by far highest areas of tropical forest clearing in the world. Its dynamic agribusiness sector has led an aggressive expansion of the agricultural frontier in the Amazon region. While Chomitz and Thomas (2001) found that more than three quarters of deforested land has ended up under pasture and, in fact, pasture continues to strongly dominate the land use mix in the Amazon. Yet, recent evidence indicates that, in relative terms, cropland expands now faster than pastures (Morton et al. 2006). Model based simulations suggest that, until 2040, primary forest clearing in the Brazilian Amazon may release up to $32 \mathrm{Pg}$ of carbon into the atmosphere -roughly twice the amount of global annual anthropogenic greenhouse gas emissions (GHGs) (Soares-Filho et al. 2006).

While farmers, the local and probably also the national economy have benefited from converting forests to agricultural land (Andersen et al. 2002), continuous deforestation does not only accelerate climate change but also threatens the provision of other important global ecosystem services, such as biodiversity protection and hydrological regulation. Thus, it seems wise to intensify the search for flexible policy mechanisms that translate the demand for such global public good services into local economic incentives for conservation.

Traditional command-and-control policies have been ineffective in curbing deforestation in the Amazon. The Código Florestal has been the prime legal instrument for forest conservation on private lands since 1965. But due to lax enforcement, illegal deforestation contributes the lion's share to forest loss in the Brazilian Amazon. During 200506, deforestation rates had dropped sharply. At the Kyoto Protocol's International Climate Change Conference COP13 in December 2007 in Bali, many hoped this was a lasting reduction, to be attributed to better rural licensing systems, increased fines for illegal clearings, and other policy actions by the Brazilian government under its ambitious Plan to Combat Deforestation. ${ }^{1}$. However, in early 2008 the Brazilian Space Research Centre (INPE) reported that deforestation has accelerated again sharply during the second half of 2007 , probably in response to the recovery of international soy and meat prices.

Enforcing command-and-control policies at the scale of the Amazon region is thus unlikely to work as a stand-alone strategy. Combining infrastructure expansion and other development policies with high food-commodity prices and rising demand for biofuels creates a cocktail that will add to Brazilian agricultural land demand and to forestconversion pressures in the foreseeable future. It is against this backdrop that the debate on Reduced Emissions from Deforestation and Forest Degradation (REDD) has gained momentum, both internationally and inside Brazil. The COP13 decided to include REDD in future negotiations on mitigation mechanisms for countries that are not listed in Protocol Annex B. Several proposals to implement REDD in the Brazilian Amazon were also presented. Drawing on its experiences with Bolsa Floresta, a pilot compensation scheme for avoided deforestation on smallholdings, Amazonas State proposed a REDD scheme at the federal state level (Government of Amazonas 2007). Second, an NGO consortium sketched the outlines of a proposed payment for environmental services (PES) scheme for avoided Amazon deforestation ${ }^{2}$. Finally, another group of NGOs presented a report scientifically underpinning a national-level REDD scheme to boost Amazon conservation (Nepstad et al. 2007). The evidence presented in the following extends on background calculations made by the authors for the first two proposals.

The challenge of quantifying potential REDD supply has both a temporal and a spatial dimension. First, credible temporal baselines are needed to project forest-cover change relatively far into the future. Second, the total cost of implementing a payment scheme has to be estimated in a spatially disaggregated manner, for many farms with variable environmental and economic conditions. Yet, scientific assessments of the supply side of Amazon REDD have so far been scarce. In a multiple-country background study for the Stern Review, Grieg-Gran (2006) estimated avoided deforestation in Brazil to cost US\$1.2-1.7 billion, depending on whether timber rents are included. Nepstad et al. (2007) expected avoiding 6.3 Pg of carbon emissions in the Amazon over 30 years to cost considerably more (US\$ 8.2 billion $)^{3}$. In spite of the diverging total cost estimates, both studies suggest that REDD at current carbon prices might be competitive vis-à-vis the conservation opportunity costs of private Amazon land development for crops and pastures.

Current Brazilian deforestation can be said to occur at four different levels of (il)legality. First, landowners can legally clear up to $20 \%$ of their land area (private landowners in the Amazon are required to keep $80 \%$ of their farm area as a Legal Forest Reserve.). Secondly, they could pass that legal clearing threshold and develop a so-called 'environmental deficit' on their land - a phenomenon that is

\footnotetext{
1 "Cutting down deforestation in the Brazilian Amazon". Report published by the Brazilian Ministry of Environment at the COP13, December 12th 2007, Bali, Indonesia.

2 Pacto pela Valorização da Floresta e pelo o fim do Desmatamento na Amazônia (Forest Valuation Pact). http://www.icv.org.br/publique/media/PactopelaValorizacaodaFlorestaepeloFimdoDesmatamento_sumario.pdf

${ }^{3}$ Per ton of carbon values are less diverging. See Section 7 for explanation.
} 
widespread (and tolerated) in many old frontier areas. Third, private individuals could invade weakly enforced state land (terra devoluta) and clear its forest, in the realistic hope of establishing land tenure over time. Finally, land invasion could happen in declared national parks, indigenous and extractive reserves, etc.

To counteract the third and fourth types of deforestation, international REDD payments could be used for financing improved command-and-control systems However, in the authors' view it makes less sense to calculate the opportunity costs of conserving these lands, especially for parks and reserves that have already been legally delimited by the Brazilian federal or a state government with the aim to ensure protection. On the contrary, this study will thus focuses on direct compensations to private landowners. This refers to the first and, possibly in the future, to the second legality scenario - given strong current political pressures to lower the $80 \%$ legal reserve threshold, or to allow landowners to somehow pay their way out of 'environmental deficits'. It is likely that PES-type compensations will become one important element in any Amazon REDD scheme. To make forest conservation attractive to landowners, such transfers have to exceed their land opportunity cost, i.e. the economic returns to converting forest to other uses minus the current economic benefits derived from the standing forest.

Hence, this aimed-for contribution to the REDD debate is twofold. First, it evaluates the economic feasibility of REDD using municipal-level production data for the private lands of two of the largest Brazilian federal states (combined 47\% of the Legal Amazon's land area). Secondly, it uses these results to provide guidance for REDD design that combines cost effectiveness with equity concerns.

The article is structured as follows. Section 2 provides a general overview of the two case study areas and the general context for REDD in the Brazilian Amazon. Section 3 describes the methods and data used to arrive at the results presented in section 4. After interpreting the results from a political economy perspective in section 5 , section 6 concludes with the main implications of this study. Finally, section 7 discusses some of the main assumptions and compares the findings with those made in other REDD opportunity cost studies. Future perspectives of REDD in the Amazon are discussed as well.

\section{STUDY AREA: BRAZILIAN AMAZON, MATO GROSSO, AND AMAZONAS}

Only roughly $25 \%$ of land in the Brazilian Amazon is private. About $35 \%$ is indigenous territory or protected by federalor state-level protected areas, whereas the remaining land is considered public with weakly enforced tenure (terra devoluta) (Toni 2006). In the state of Amazonas, over $30 \%$ of total surface area are covered by either indigenous territories or protected areas, as opposed to $20 \%$ in Mato Grosso. As suggested in Table 1, land concentration is comparatively high in the Amazon, with regional Gini indices constantly being around 0.85 since 1950: it was reduced from 0.9 to 0.8 in Amazonas, and remained almost constant at 0.85 in Mato Grosso (ADA 2002). Both the small share of private lands and the high concentration of land ownership have important implications for REDD, which will be addressed in Section 5.

Figure 1 shows the location as well as the main terrestrial and fluvial access ways of Mato Grosso and Amazonas, while some comparative statistical figures are given in Table 1. Amazonas is the largest and second-least densely populated federal state in Brazil. Per-capita income is among the lowest in Brazil -- especially outside the capital Manaus with its free-trade zone, which is mainly accessible through fluvial transport. Amazonas is remotely located from the main Brazilian markets in the South. Despite some largescale cattle operations, more that a third of private land is constituted by smallholdings - in Brazil defined as farms sized below 100 ha. Annual and permanent crops hold about equal the same share as pasture (about $40 \%$ ) in its diversified land use mix. The state has over the last years implemented many environmentally friendly policies, increasing protected areas and creating positive incentives for conservation. As a combined result of economics and policies, deforestation in Amazonas has been low, both in absolute and relative terms.

In comparison, Mato Grosso is located in the heart of the so-called 'Arc of Deforestation' at the southern end of the Amazon. It disposes of a relatively dense road network and is well connected to the main population centers in the Brazilian Center-South regions. Mato Grosso has a strong commercial agricultural sector, dominated by extensive cattle and soy production Grosso (IBGE 1995/6). Soy and cattle expansion are also responsible for Mato Grosso being the Brazilian state with highest deforestation (in the last decade more than one third of total forest loss in the Brazilian Amazon). The state has historically adopted policies that favour landextensive economic development. In 1999, the government of Mato Grosso introduced a Licensing System for Rural Properties (SLAPR) (Fearnside 2003), which was believed by many to have mainly caused the falling deforestation rates after 2004. Enrolment in the SLAPR is, however, still below $30 \%$, and much of the recent pick-up in deforestation has been registered in Mato Grosso ${ }^{4}$.

Figure 2 shows the distribution of average 2000-6 deforestation rates in Amazonas and Mato Grosso, which will also serve as baselines for future deforestation in the REDD opportunity-costs calculations below. In both relative and absolute terms, deforestation is far higher in Mato Grosso than in Amazonas. Although growth in total land under agricultural crops (in Mato Grosso, especially soy) has been faster than expansion of pastures, pasture still remains

4 Brazilian Space Research Institute (INPE): Online Communication 24.01.200 8 (http://www.inpe.br/noticias/noticia.php?Cod_ Noticia=1318) 
FIGURE 1 Location and main transport ways of the states of Amazonas and Mato Grosso

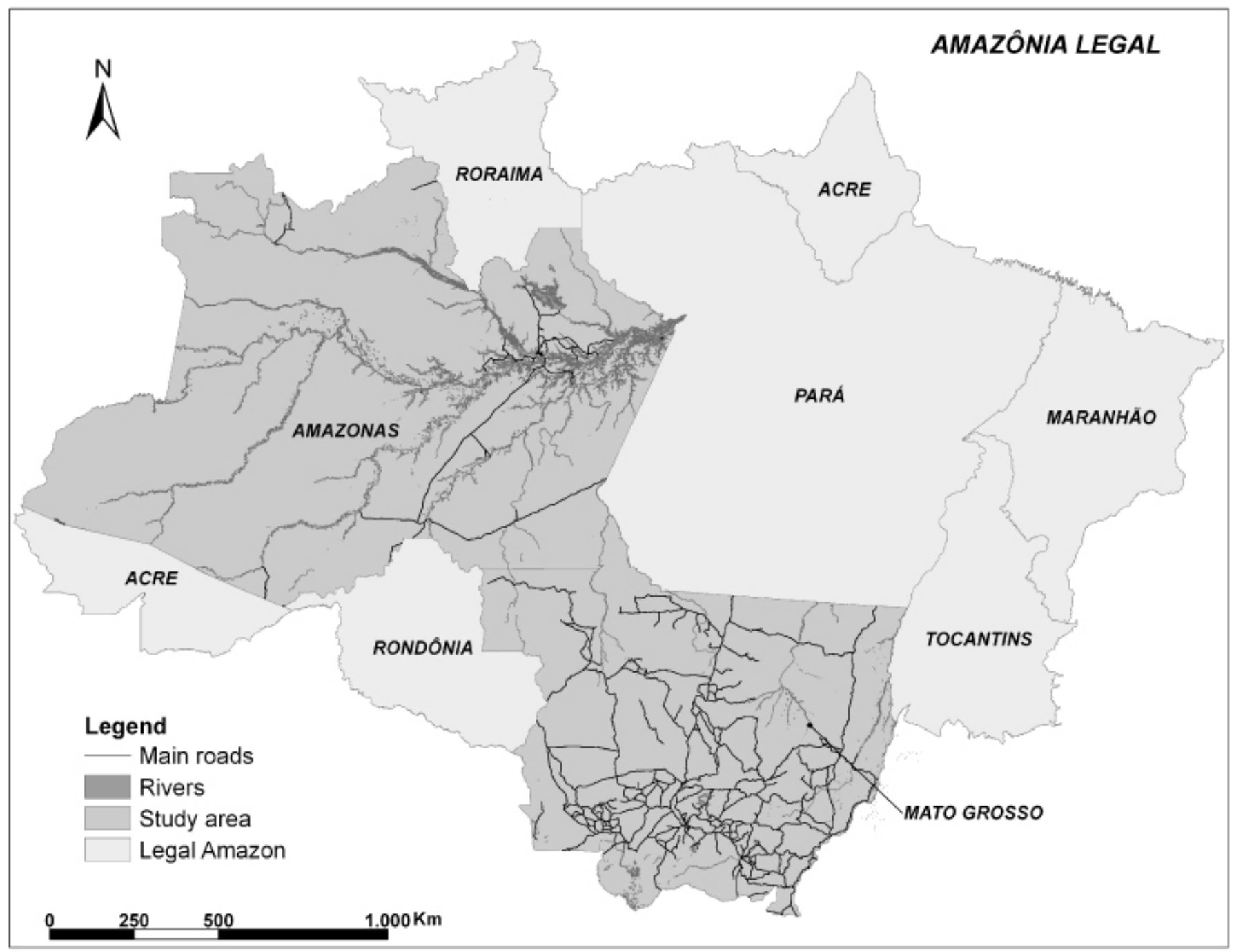

TABLE 1 Key features of Amazonas (AM) and Mato Grosso (MT) states

\begin{tabular}{lcccc}
\hline & Units & AM & MT & Brazil \\
\hline \hline Area & {$\left[\right.$ million $\left.\mathrm{km}^{2}\right]$} & 1.57 & 0.90 & 8.51 \\
\hline Forest cover (2006) & {$[\%]$} & 90 & 36 & 56 \\
\hline Forest carbon (2006) & {$[$ Mt C] } & 16000 & 3600 & n.a. \\
\hline Average annual forest loss (2000-6) & {$\left[\mathrm{km}^{2}(\%)\right]$} & $910(0.1)$ & $6650(2.5)$ & $31030(0.6) *$ \\
\hline Population density (2000) & {$[$ people per } \\
$\left.\mathrm{km}^{2}\right]$ & 1.79 & 2.77 & 19.92 \\
\hline Income per capita (2000) & {$[$ US\$ per year] } & 1148 & 901 & 1962 \\
\hline Share of farms smaller than 100 ha (1995/6) & {$[\%]$} & 94 & 60 & 10 \\
\hline Total area of farms smaller than 100 ha (1995/6) & {$[\%]$} & 35 & 4 & 80 \\
\hline
\end{tabular}

Sources: UNDP, IBGE, FAO, Houghton et al. (2001)

*Calculated from FAO data (2000-5) 


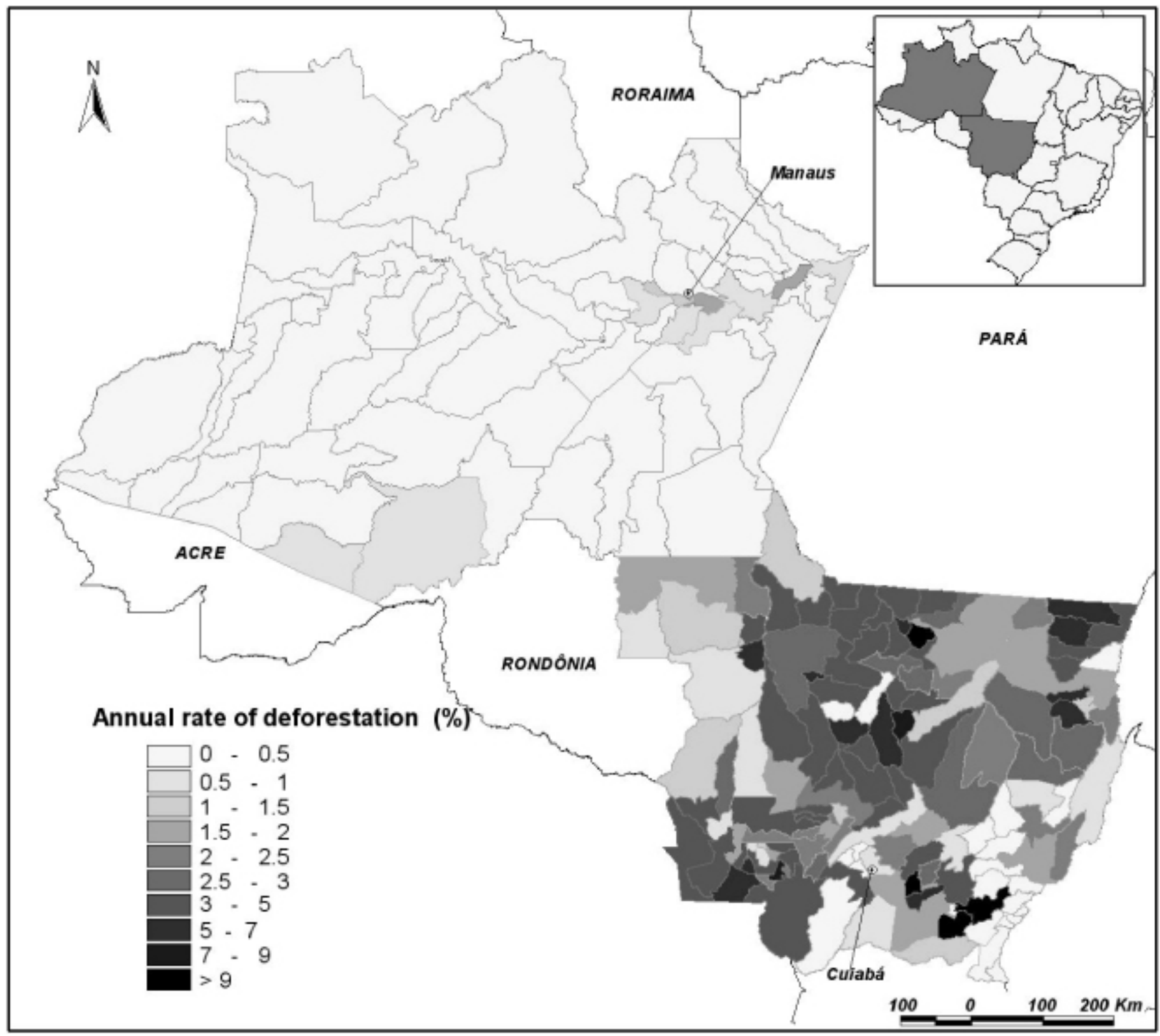

the predominant converted land cover in both Amazonas and Mato Grosso. As Figure 3 shows, soybeans have started to dominate the land-use mix in a few municipalities in the centre and southeast of Mato Grosso. In Amazonas, crops have generally a higher share in the municipal crop mix than in Mato Grosso, due to the more diverse and subsistenceoriented smallholder sector. In the westernmost remote municipalities in Amazonas, the little land that was converted during 2000-06 is exclusively covered by crops, a fact that to some extent may be explained by their large indigenous territories. In both soybean- and pasture-dominated areas, deforestation rates are high in Mato Grosso, suggesting that both activities contributed considerably to forest loss.

\section{DATA AND METHODS}

One can estimate the opportunity costs of forest conservation using various approaches, ranging from economic optimization or general equilibrium models (Cattaneo 2002, Börner et al. 2007) to land prices being used as surrogates for the discounted stream of future deforestation returns - see Grieg-Gran (2006) for a discussion. Nepstad et al. (2007) calculate REDD opportunity costs REDD based on simulated returns to soy and cattle production on land their model predicts to be cleared in the future. In their approach, land opportunity costs depend heavily on distance to roads and on suitable soil and climate conditions. 


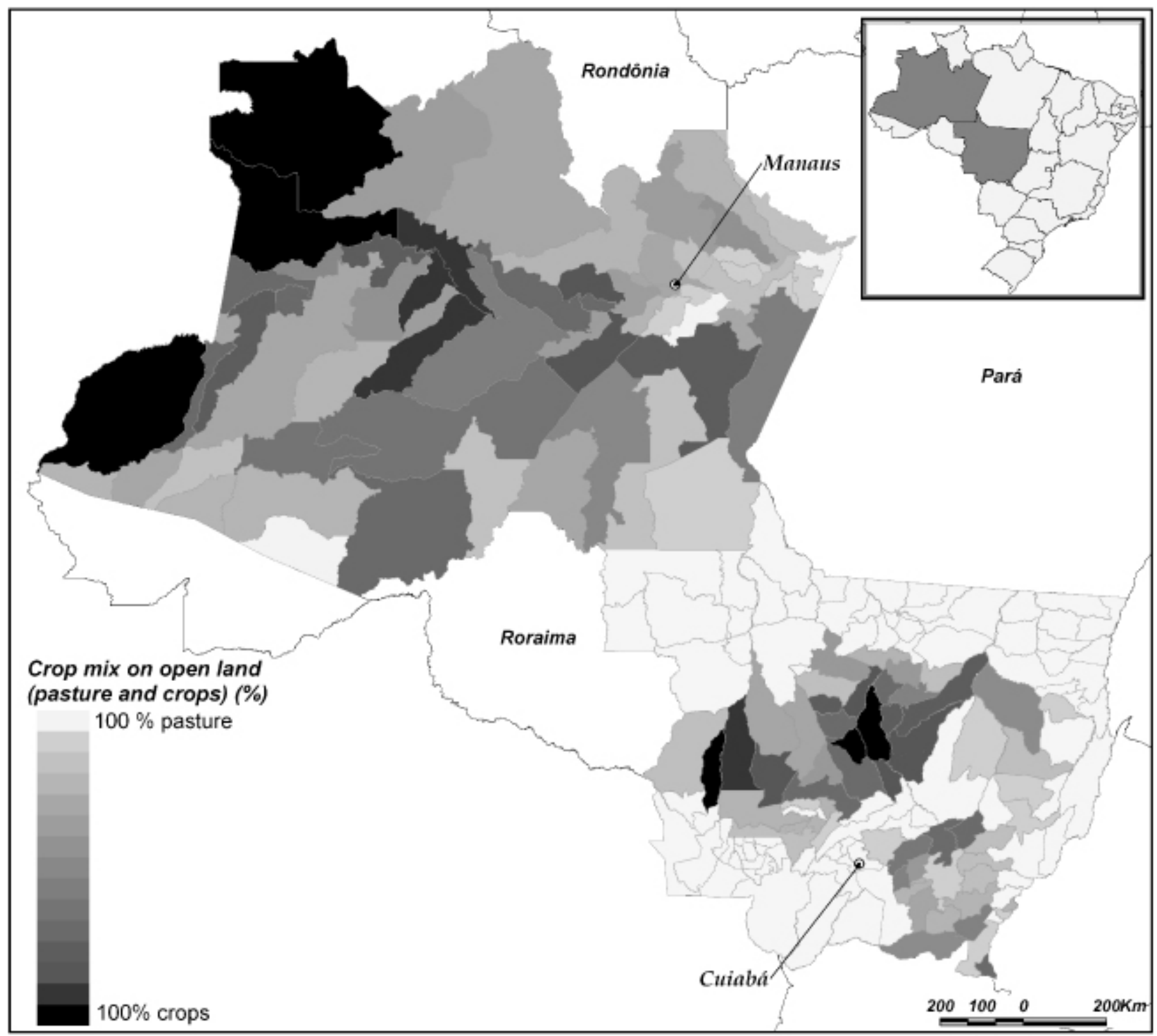

Below opportunity costs are estimated using a complementary method, based on municipal agricultural production data from the Brazilian Institute for Geography and Statistics (IBGE). The IBGE Municipal Agricultural, Animal, and Extractive Production data base (PAM/PPM/ PEV) holds annual information about total cultivated area, yields and total production value for all Brazilian municipalities. These data are not field measurements, but expert estimates collected in annual consultations of local extension agents, government officials and IBGE staff. Comparisons with the latest agricultural census (1995/96) suggest that PAM/PPM/PEV data have historically been reasonably accurate as far as municipal averages of yields and prices are concerned. Meanwhile, satellite-based annual deforestation measurements from INPE are frequently higher than the PAM/PPM/PEV estimated growth in cattle herds and cultivated area, which leads us to be less confident in the latter. In the Amazon region, technical coefficient and cost information is not available at municipality levels. The estimates thus heavily rely on national-level profitability estimates for main agricultural crops from the Brazilian Agriculture Yearbook (FNP 2007) and Amazon-specific estimates by Margulis (2004) for cattle ranching and Pokorny and Steinbrenner (2005) and Barreto et al. (1998) for timber harvesting.

The opportunity-cost estimation is limited to private landholdings, given that direct payments to farmers invading public lands could easily create perverse incentives for additional forest clearing. For Amazonas State, calculations rely on the rural land register published by the National Institute for Colonization and Agricultural Reform (INCRA). The INCRA data are often inconsistent 
with agricultural census information, which reflects the considerable uncertainty with regard to land-tenure data in Brazil. Especially in Mato Grosso, where aggressive land grabbing has taken place for many years, INCRA data are also inconsistent with municipal boundaries. Hence, INCRA data are used only for Amazonas, whereas estimates for Mato Grosso are restricted to farms registered in the SLAPR (i.e. roughly $25 \%$ of farms in the rainforest areas of the state).

Figure 4 depicts the main analytical steps to calculate opportunity cost of REDD. Municipal-level past deforestation rates are calculated from INPE PRODES ${ }^{5}$ data and linearly projected into the future for 2007-16. INCRA and SLAPR data serve as the basis for calculating the share of private land in each municipality. While the SLAPR database for Mato Grosso directly records remaining forests on private land, for Amazonas forestland on private properties needs to be calculated. It is assumed that the amount of forest left in Amazonas corresponds to total private land less land currently under pastures and crops. This may overestimate remaining forests in 2006, as one would expect a minor share of private land to be in fallow (3\% in the agricultural census of 1995/6).

As mentioned, land-use mixes for each municipality are calculated on the basis of PAM and PPM data. PPM data on cattle-herd size per municipality is used to impute pasture cover, assuming 1995/96 stocking rates to remain constant in both states. State-level expansion rates of pastures and crops (permanent and annual) are then applied to estimate expansion of land use categories, such as annual subsistence crops produced in slash-and-burn systems, traditional cash crops, fibres, and fruits. Each land-use category is represented by the single crop with the highest share in 2000-6 total land use expansion, e.g. soy beans for the category cash crops in Mato Grosso.

Gross per-hectare returns of crops are calculated from PAM and PEV data. No such information is available for timber extraction, so yields and per-ton extraction costs reported by Pokorny and Steinbrenner (2005) and Barreto et al. (1998) are used in calculations for Amazonas. Timber yields for Mato Grosso were adjusted according to estimates provided by the Forest Management Unit of the Environmental Secretariat of Mato Grosso ${ }^{6}$. Gross returns from each selected land-use category are converted to net profits as follows:

(1) $\Pi_{i}=G R_{i} *\left(1-\frac{c}{b}\right)$

where $\Pi$ is net per-ha profit in municipality i, GR are annual gross per-ha returns in municipality i calculated from the $\mathrm{PAM} / \mathrm{PPM} / \mathrm{PEV}$ data base, whereas $\mathrm{b}$ and $\mathrm{c}$ are per-ha gross returns and total costs, respectively, derived from other sources. Profitability of extensive cattle operations is taken from Margulis (2004), assuming his high-end estimates to apply for Mato Grosso and low-end estimates for Amazonas

FIGURE 4 Data sources and calculation steps for REDD opportunity costs.
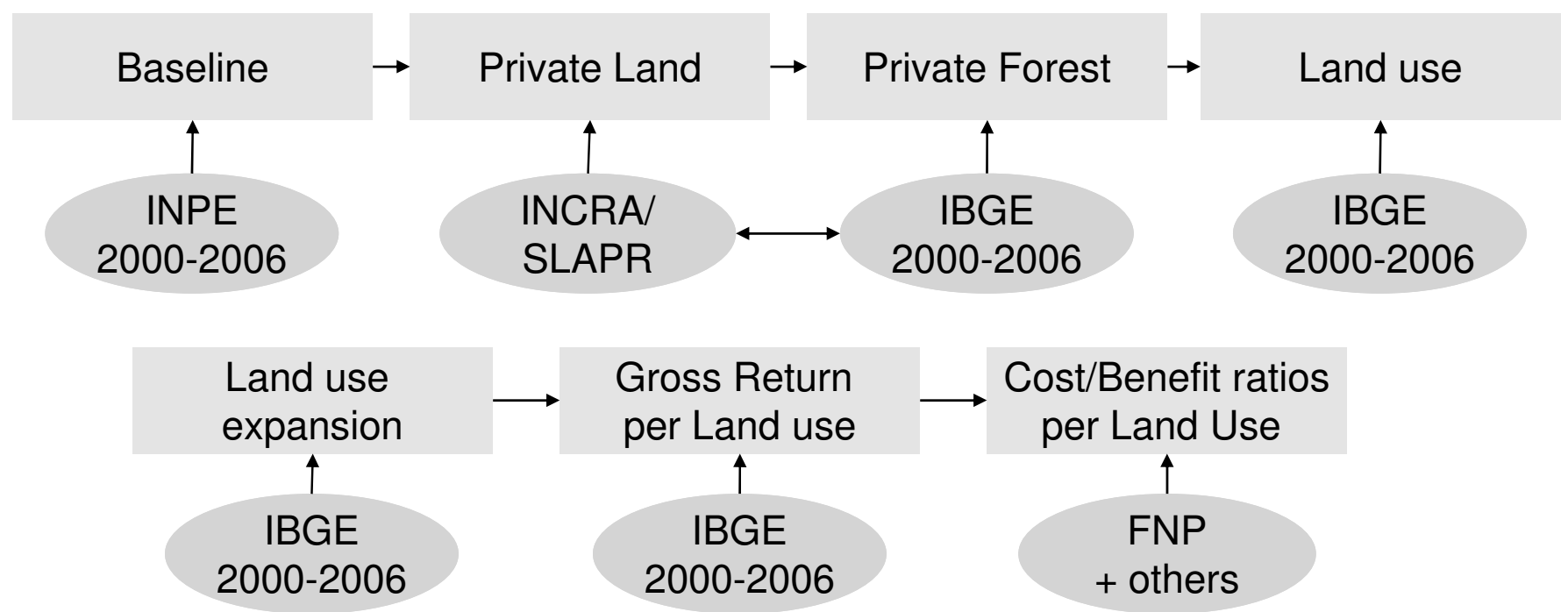

Opportunity cost

(PES scenario)

\footnotetext{
5 INPE's Program for the Calculation of Deforestation in the Amazon (PRODES) publishes annual deforestation estimates for the Amazon.

${ }^{6}$ Personal Communication: Secretariat of the Environment (SEMA), Forest Management Unit 13.05.2007
} 
(cattle ranching being less capitalized in the latter than in the former).

Vosti et al. (2002), among others, show that deforestation is typically followed by distinct land-use trajectories, e.g. with annual subsistence crops being the first rotation after forest clearance, followed by conversion to pastures. Hypothetical land-use sequences for the expanding land use categories are therefore identified in step five of Figure 4. Examples of such sequences are shown in a stylized form in Figure 5.

FIGURE 5 Stylised sequences of land uses applied in the opportunity-cost estimations

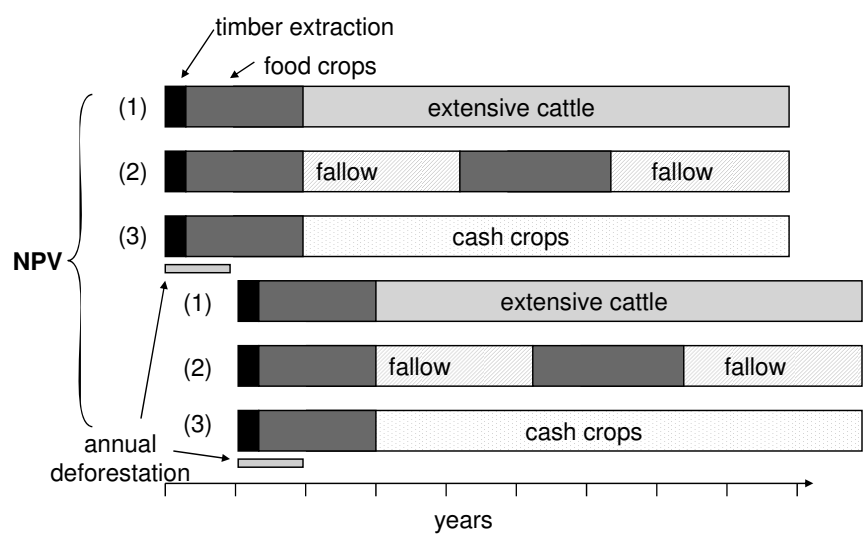

Note: Percentages represent hypothetical shares in the municipal land-use mix

Figure 5 depicts how total opportunity costs at the municipal level are calculated from individual land-use sequences at the plot level. All land use trajectories start with timber extraction followed by subsistence-crop production in the second year, but then some land goes into pasture (1), some into crop-fallow cycles (2), while other land is used for cash crops (3). Net present values (NPV) of all land use sequences are reported in Table 2 below. During years $3-10$, the main land-use category follows. Since the same amount of new land is assumed to be opened each year, the ten-year period 2007-16 covers the accumulated NPV of the benefits derived from the corresponding cultivation cycles (see equation 2). The municipal land-use mix is considered constant for all subcategories, but it is annually adjusted according to the state-level growth rates of agricultural land vs. pastures during 2000-06.

(2) $N P V_{\text {total }}=\sum_{t=1}^{10} \frac{N P V_{t}}{(1+r)^{t}}$

where $N P V_{\text {total }}$ is the opportunity cost for a given municipality, $N P V_{t}$ is the net present value of a plot-level ten-year land use trajectory in year $t$, and $r$ is the discount rate.
Finally, transport costs are accounted for by creating a cost index reducing net returns proportionally to the distance of a given municipality to the state capital. Transport costs are assumed to reduce net returns by a maximum of $20 \%$. Hence, it is ignored that bulk density and difficult access conditions in the remotest areas could lead to more considerable reductions in net profits, due to extreme transport costs.

\section{ANALYSIS AND RESULTS}

\section{How large gains would landowners forego?}

Table 2 presents average profits calculated for the main expanding land-use categories in Amazonas and Mato Grosso. It clearly shows that soybean plantations are the most profitable land-use option among those that contribute to forest loss in the two states. For the sake of simplicity, it is assumed that current returns from standing forests are nil, so that the profits from converted uses are identical to the conservation opportunity costs.

Note that the NPV values for land-use sequences are strongly influenced by the returns to timber extraction in those municipalities that report timber extraction in past years. Due to fallow periods, during which returns to land are zero, NPV for staple crops is considerably lower than to cattle production, even though average annual returns are equal. Values in the last column of Table 2 show the share of each land-use category in total 2000-6 expansion of agricultural land. In the case of crop categories, these values correspond to the crops shown in brackets in the first column that were selected as described in the previous section.

Opportunity costs per ton of carbon dioxide (the commonly traded unit) depend heavily on the amount of biomass and, hence, carbon content per hectare of primary forest, which varies widely across the Amazon region (Saatchi et al. 2007). Houghton et al. (2001) present data from seven independent studies analysing carbon content of forest biomass in the Amazon. To provide a conservative estimate of opportunity costs, this study adopts the lowest estimate presented in the Houghton et al. study $(110 \mathrm{Mg}$ $\mathrm{C}$ per ha) for forests in the state of Amazonas, and assume that $20 \%$ of this would be kept as an insurance reserve. For Mato Grosso, the same procedure was applied to more detailed carbon content data provided to us by the Instituto Centro de Vida (ICV) ${ }^{7}$.

\section{Spatial distribution and abatement cost curves}

Figure 6 shows average REDD opportunity costs per ton of carbon dioxide at the municipal level. Average values are

\footnotetext{
7 Instituto Centro de Vida (www.icv.org.br) is a subscriber to the Forest Valuation Pact, and was intensively involved in the research underlying the Pact.
} 
highest in Mato Grosso, although many municipalities with high opportunity costs lie in savanna (cerrado) regions ${ }^{8}$ with lower natural biomass density. In Amazonas, many high opportunity cost municipalities lie alongside road and fluvial transport ways (see Figure 1). Opportunity cost differences in pasture-dominated parts of Mato Grosso are mainly caused by high returns to timber extraction prior to forest conversion. In general, opportunity costs differ remarkably across space -- not only between but also within the two states.

Figures 7 and 8 present carbon-dioxide emission abatement costs (REDD supply curves) for Amazonas and Mato Grosso, respectively. As a benchmark, both figures include 2006 average prices for permanent carbon credits traded at the Chicago Climate Exchange (CCX) carbon market. However, since the authors expect that REDD payments are likely to be introduced in the form of temporary carbon credits, the figure shows a hypothetical price line with a $39 \%$ rebate on current CCX prices that is considered more cautionary (Dutschke and Schlamadinger, 2003). The grey 'bands' in Figures 7 and 8 show the result of sensitivity analyses varying key parameters such as product prices and per-ha carbon content by $\pm 30 \%$, to account for both expected market fluctuations and perceived uncertainties.

The supply curve for Amazonas shows that more than one third of deforestation is worth less than $\mathrm{US} \$ 1 / \mathrm{tCO}$, and thus profitable to buy out under almost any carbon-market scenario. Going towards the right the curve starts sloping, but there is in Amazonas no deforestation worth more than US $\$ 3 / \mathrm{tCO}_{2}$-- at least at the aggregated municipal-average level. The situation is slightly different in Mato Grosso. While around half of deforestation is worth less than US\$3/
$\mathrm{tCO}_{2}$, with a relatively flat curve, the other half is more heterogeneous and rises to values around US\$12/tCO .

\section{How much REDD is economically feasible?}

What does this mean for the competitiveness of REDD as a land-use option? Table 3 compares the opportunity-cost results in Mato Grosso's SLAPR areas and in Amazonas State to three carbon-price situations (rows 1-3):

(1) maximum price (i.e. the hypothetical price needed to buy out all deforestation)

(2) permanent CCX price (value in 2006)

(3) temporary CCX price (same as (2), but with a $39 \%$ discount - see above).

On the payment side, two generic scenarios (two last columns) are shown. First, "opportunity-cost payment" (Scenario I) implies that each farm receives differentiated compensation payments corresponding to their pure opportunity cost values. Graphically, this corresponds to the area under the emission abatement-cost curves in Figure 7 and 8 . The (extreme) assumption here is that payments can be perfectly differentiated, so that provider economic rents are fully eliminated. Secondly, under "marginal pricing" (Scenario II) all providers receive the same uniform payment, determined by the farm with the highest opportunity cost. Graphically, payment value thus not only corresponds to the area under the supply curve, but to the entire price-times-quantity rectangle: cheap REDD suppliers (on the left-hand side of the curve) capture a "provider surplus", i.e. the difference between the market price and their individually lower costs

TABLE 2 Net returns and importance of crops and land use categories in the opportunity cost estimation

\begin{tabular}{|c|c|c|c|c|}
\hline & Total net return & $\begin{array}{c}\text { Average annual net } \\
\text { return }\end{array}$ & $\begin{array}{c}\text { Average NPV } \\
\text { of Land Use } \\
\text { Trajectory } \\
\end{array}$ & $\begin{array}{l}\text { Share in total 2000- } \\
\text { 06 expansion* }\end{array}$ \\
\hline & [US\$/ha] & [US\$/ha] & [US\$/ha] & {$[\%]$} \\
\hline \multicolumn{5}{|l|}{ Amazonas } \\
\hline Timber extraction & $24-791$ & - & - & \\
\hline Extensive cattle ranching & - & 39 & 694 & 86 \\
\hline Food crops (corn) & - & 39 & 475 & 6 \\
\hline Cash crops (coffee) & - & 93 & 650 & 3 \\
\hline Fruits (water melons) & - & 41 & 393 & 1 \\
\hline Fibres (malva) & - & 24 & 307 & 4 \\
\hline \multicolumn{5}{|l|}{ Mato Grosso } \\
\hline Timber extraction & $109-734$ & - & & \\
\hline Extensive cattle ranching & - & 59 & 719 & 84 \\
\hline Cash crops (soybeans) & - & 171 & 1080 & 16 \\
\hline
\end{tabular}

\footnotetext{
${ }^{8}$ Municipalities were defined as being "savanna-dominated" if savanna areas were larger than forest areas. However, only areas classified as forest in the INPE data base were considered in this study's calculations.
} 


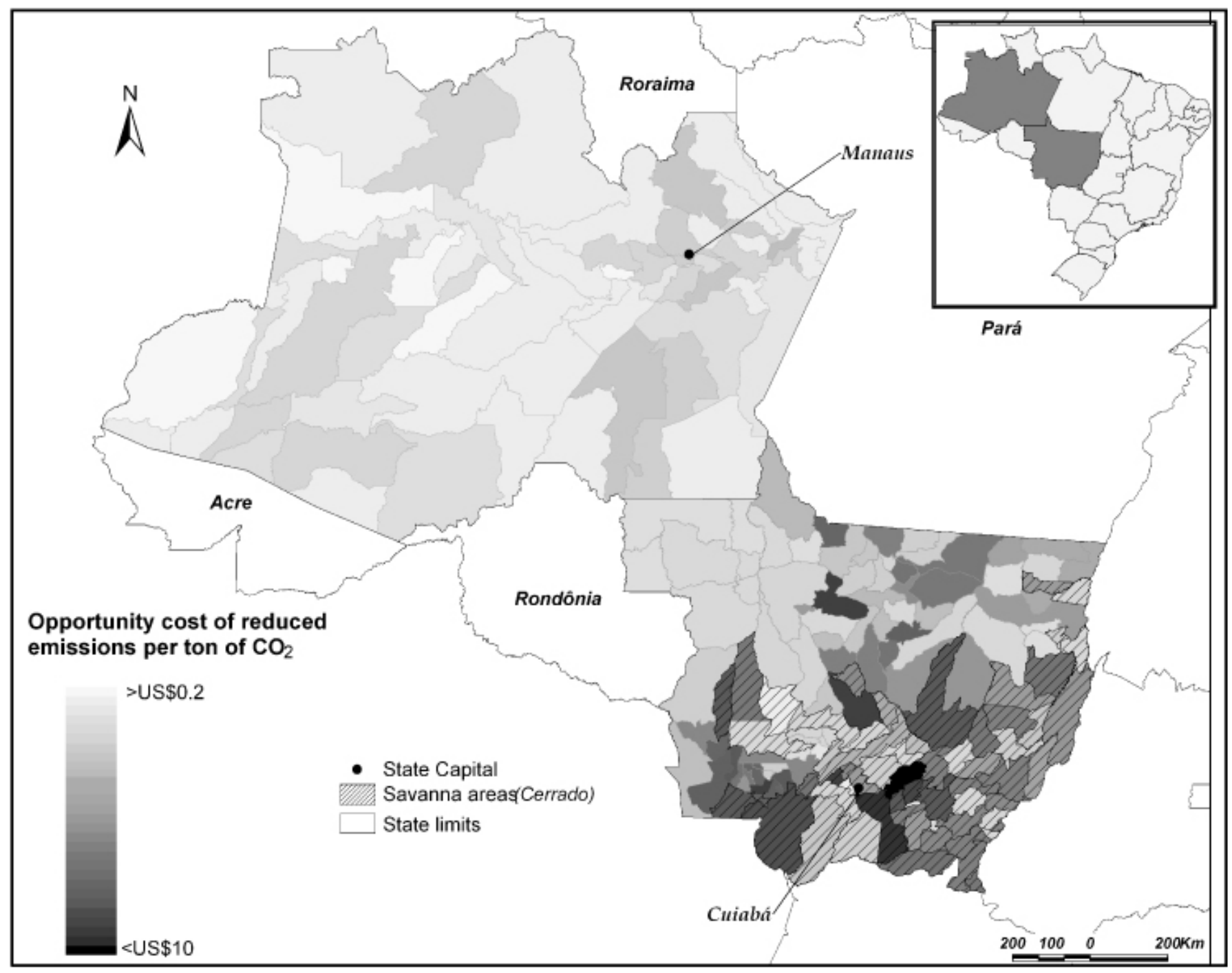

of supplying REDD. For the moment all calculations assume zero transaction costs (to be relaxed in next section).

The maximum carbon price (row 1) needed to compensate all deforestation costs would be almost US $\$ 13 / \mathrm{tCO}_{2}-$ most of all due to a few municipalities with very high conservation opportunity costs in Mato Grosso's SLAPR areas. Focusing first on Scenario I (pure opportunity-cost compensation), this would lead to payments of US\$680 million to achieve zero deforestation in all SLAPR areas of Mato Grosso by fully covering all producers' economic returns from deforestation. In Amazonas, the total would be only US $\$ 143$ million, both because there is less deforestation and because the average per-hectare opportunity cost there is lower. At permanent CCX prices of US $\$ 3.88 / \mathrm{tCO}_{2}$ in 2006 (row 2), two thirds of Mato Grosso's SLAPR deforestation would be compensable, at a total cost of US\$381 million; for Amazonas all forest loss is still being compensated for. At temporary CCX prices of US\$2.32/ $\mathrm{tCO}_{2}$ (row 3) - the scenario the authors consider the most realistic $-40 \%$ of SLAPR areas enter REDD at costs of US\$212 million, while 93\% of Amazonas deforestation is compensated for at US\$123 million. Hence, at current carbon price ranges, the bulk of deforestation can potentially be compensated, especially on the lower-value lands that predominate in Amazonas.

What if one has to compensate farmers at a fixed marginally determined price, rather than 'just' their pure individual opportunity costs (Scenario II, last column)? Obviously, this does not change the amount of forest area protected, but distribution-wise a 'provider's surplus' is created, thus increasing costs. Potentially, this economic rent can be sizeable, the higher is the carbon price and the more heterogeneous are producer costs. For the maximum price situation (line 1), costs in Mato Grosso's SLAPR areas would quadruple to US\$2.7 billion, three fourths of which would accrue to low-cost suppliers as windfall gains (i.e. compensations paid in excess of opportunity costs). At temporary carbon prices (3), these gains are less astronomic. For instance, for Mato Grosso's SLAPR areas the costs rise only from US\$212 to US274, since this corresponds to the low-sloping section of the supply curve. But for Amazonas, costs still more than double, from US\$123 to US\$239 million, because a large part of Amazonas' potential REDD 
FIGURE 7 Opportunity cost per avoided ton of carbon dioxide in the State of Amazonas.

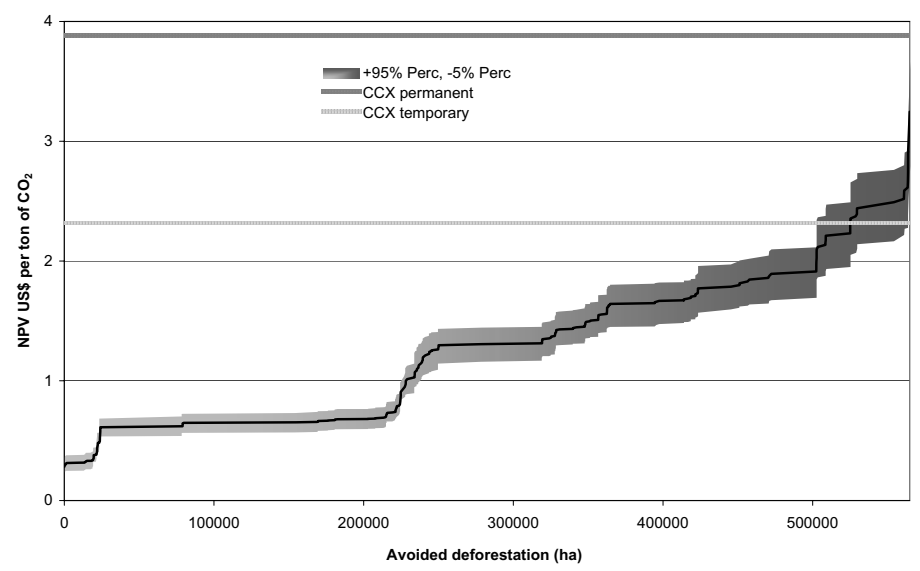

Notes:

- CCX permanent - full average price of per ton of $\mathrm{CO}_{2}$ at Chicago Climate Exchange

- CCX temporary -- includes a $39 \%$ rebate on permanent carbon prices.

- Grey areas represent values that lie in a 5-95\% sensitivity range.

FIGURE 8 Opportunity cost per avoided ton of carbon dioxide in the State of Mato Grosso.

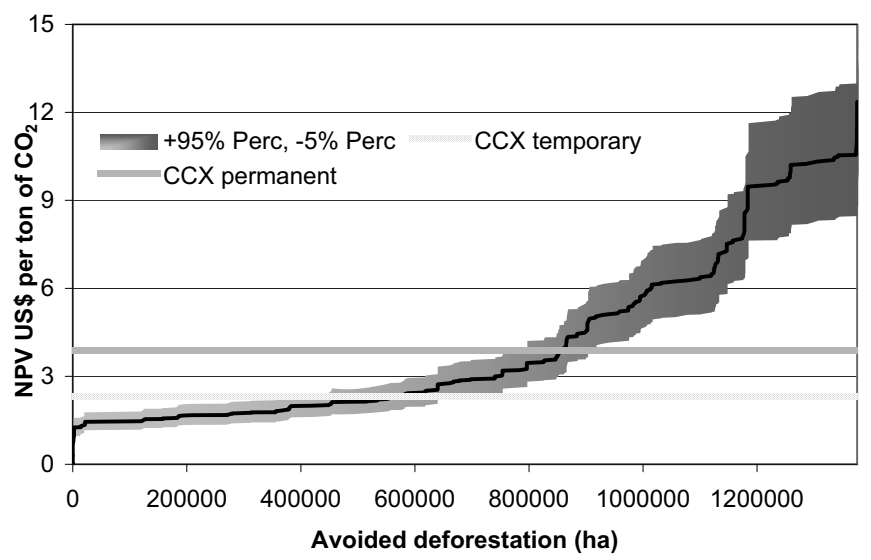

Notes:

- CCX permanent - full average price of per ton of $\mathrm{CO} 2$ at Chicago Climate Exchange

- CCX temporary -- includes a $39 \%$ rebate on permanent carbon prices.

- Grey areas represent values that lie in a 5-95\% sensitivity range.

credits are very low-cost and would fetch economic rents even under moderate prices.

These findings for Scenario II have important implications for REDD design. Rising carbon prices would multiply economic rents accruing to low-cost providers. There would thus be large efficiency gains for REDD buyers in introducing some sort of differentiated payment system (according to location, producer types, land values, etc.) that caters to highly variable provider opportunity costs. The flip side is that price differentiation would also eat into the 'provider's surplus', which represents the potential welfare gains on behalf of farmers, including for poverty alleviation. In practice, probably neither a uniform nor a fully differentiated price is very likely, but for analytical purposes they represent extreme scenarios that help us understand the competitive and distributional consequences of different payment modalities.

The results prove to be particularly sensitive to the returns from timber extraction. One-off timber rents can in some cases be sizeable, and since they accrue at the beginning of each land-use cycle, they are not being time-discounted. They can thus potentially gain high influence on the overall NPV results. However, timber rents are also often at least partially captured by actors other than the landowner proper, and their harvesting may happen well in advance (and causally divorced) from the deforestation process proper. Setting timber extraction profits to zero, for analytical purposes, would allow REDD transfers at temporary CCX prices to compensate more than $80 \%$ of forest loss in Mato Grosso and $100 \%$ of forest loss in Amazonas at current (temporary) carbon prices. This reconfirms that the timber economy, and the second " $D$ " in REDD, merit further analysis.

Apart from timber rents, total opportunity costs are most sensitive to beef prices, e.g. a $30 \%$ price reduction decreases total opportunity costs by $9 \%$ in Mato Grosso and $10 \%$ in Amazonas, followed by soybean prices (Mato Grosso) and food crop prices (Amazonas), which is due to the dominance of the related land uses in overall crop mix. Prices per ton of carbon dioxide are particularly (and proportionally) sensitive to changes in the amount of tradable emission reductions assumed per hectare of avoided deforestation. Finally, discount rate changes also affect total opportunity costs to a considerable extent. For example, reducing the assumed $10 \%$ discount rate to $5 \%$ would increase total costs in Mato Grosso by roughly one third.

\section{How large could transaction costs be?}

Of course, opportunity costs are only one part of the story: transaction costs also need to be paid for through the REDD resources. Relatively little is known about the transaction costs of payments for environmental services (PES) schemes in general, less so for still to-be-developed direct REDD compensations to landowners. Transaction costs are defined all costs of the payment schemes that are not transfers proper. Transaction costs occur both on behalf of the carbon buyer (e.g. having to monitor compliance) and the buyer (e.g. having to document landholdings and cash in payments).

Ex-ante transaction-cost estimates have to be interpreted with caution. May et al. (2003) note that many incipient carbon-based PES schemes have incurred extremely high transaction costs, mainly because of the difficulties involved in developing forest carbon projects in an uncertain market environment. As a consequence, pioneering carbon investors have required projects to repeatedly revise strategies throughout project implementation. In general, PES schemes seem to require relatively large start-up costs, while running costs tend to be more manageable, as shown for a series of carbon projects in Indonesia (Cacho et al. 2005). 
TABLE 3 Opportunity costs and area coverage in Mato Grosso (SLAPR) and Amazonas under different payment scenarios and carbon prices

\begin{tabular}{|c|c|c|c|c|c|}
\hline & \multirow[b]{3}{*}{ Units } & \multicolumn{2}{|l|}{ Scenario I } & \multicolumn{2}{|l|}{ Scenario II } \\
\hline & & \multicolumn{2}{|c|}{ Opportunity cost payment } & \multicolumn{2}{|c|}{ Marginal pricing payment } \\
\hline & & Mato Grosso & Amazonas & Mato Grosso & Amazonas \\
\hline \multicolumn{6}{|c|}{$\begin{array}{l}\text { (1) Maximum price (MT US\$/ } \\
\left.\text { tC } \mathrm{O}_{2} 12.36\right) \text { and (AM US } \$ / \mathrm{CO}_{2} \\
3.24) *\end{array}$} \\
\hline Total opportunity cost & mill US\$ & 680 & 143 & 2745 & 363 \\
\hline Reduced forest loss & $\%$ & 100 & 100 & 100 & 100 \\
\hline Reduced forest loss & ha & 1375385 & 564849 & 1375385 & 564849 \\
\hline \multicolumn{6}{|c|}{$\begin{array}{l}\text { (2) CCX permanent price (US\$/ } \\
\left.\mathrm{tCO}_{2} 3.88\right)\end{array}$} \\
\hline Opportunity cost & mill US\$ & 381 & 143 & 677 & 363 \\
\hline Reduced forest loss & $\%$ & 62 & 100 & 62 & 100 \\
\hline Reduced forest loss & ha & 850122 & 564849 & 850122 & 564849 \\
\hline \multicolumn{6}{|c|}{$\begin{array}{l}\text { (3) CCX temporary price (US\$/ } \\
\left.\mathrm{tCO}_{2} 2.32\right)\end{array}$} \\
\hline Opportunity cost & mill US\$ & 212 & 123 & 274 & 239 \\
\hline Reduced forest loss & $\%$ & 40 & 93 & 40 & 93 \\
\hline Reduced forest loss & $h a$ & 554842 & 525094 & 554842 & 525094 \\
\hline
\end{tabular}

TABLE 4 REDD transaction costs and implications for REDD in the Amazon

\begin{tabular}{|c|c|}
\hline Transaction cost category & Comments \\
\hline 1. Information and procurement & $\begin{array}{l}\text { Currently, carbon markets are not prepared for large-scale REDD in the Amazon and } \\
\text { carbon buyers have traditionally been reluctant to invest in carbon projects in the } \\
\text { forestry sector. Procurement costs can therefore be expected to be significant. }\end{array}$ \\
\hline 2. Scheme design and negotiation & $\begin{array}{l}\text { Large-scale REDD schemes may incur significant negotiation costs, especially if they } \\
\text { contemplate payments from national government budgets that need to be negotiated } \\
\text { with the civil society. }\end{array}$ \\
\hline 3. Implementation & $\begin{array}{l}\text { Existing organisations and institutions needed to be strengthened and systems like } \\
\text { SLAPR implemented in all areas covered by REDD. Establishing and running } \\
\text { payment mechanisms (especially in the case of direct payments to landowners) are } \\
\text { likely to contribute the lion's share to this cost item. }\end{array}$ \\
\hline 4. Monitoring & $\begin{array}{l}\text { In some states, rural licensing systems are in place that would allow annual } \\
\text { deforestation monitoring at farm-level scales. } \\
\text { The technology for satellite-based deforestation monitoring is relatively well } \\
\text { developed and much more cost-effective than ground-based monitoring. }\end{array}$ \\
\hline 5. Enforcement and protection & $\begin{array}{l}\text { Enforcement costs might be considerably reduced by delivering payments only after } \\
\text { verification of effectively avoided deforestation. Given weakly enforced property } \\
\text { rights in large parts of the Amazon, enforcing theses rights (e.g. in and around } \\
\text { protected areas) might prove crucial to assuring additionally of REDD and, hence, } \\
\text { represent a relevant source of transaction costs. }\end{array}$ \\
\hline $\begin{array}{l}\text { 7. Verification and certification } \\
\text { (Approval) }\end{array}$ & $\begin{array}{l}\text { These cost items have shown to be an important barrier for small-scale carbon } \\
\text { forestry projects (Cacho et al., 2005), but are expected to decrease with project size. }\end{array}$ \\
\hline
\end{tabular}

Source: Adapted from Milne (1999)

Turning to South America, in two Ecuadorian PES cases of Pimampiro (watershed protection) and PROFAFOR (carbon sequestration), start-up costs were US\$76/ha and US\$184/ha, respectively, while recurrent annual per-hectare transaction costs in the operational phase were only US\$7 and US\$3
(Wunder and Albán 2007). In the Amazon, the authors expect transaction costs to arise mainly in the categories presented in Table 4.

Based on information from Environmental Secretariat of Mato Grosso, a hypothetical state-level REDD scenario 
was set up. The scenario involves the creation of a carbon payment fund that cooperates with existing government and civil society organizations in implementing direct REDD payments to land owners in Mato Grosso. Then, likely transaction costs in the categories 3., 4., and 7. of Table 4 are preliminary assessed. Start up costs are estimated at US $\$ 7.5 /$ ha and annual implementation costs at US $\$ 4.5 /$ ha of avoided forest loss. Recurrent costs are thus slightly higher than what Grieg-Gran (2006) calculated for the Costa Rican national PES scheme (US\$3/ha/yr). Depending on biomass density, transaction costs in Mato Grosso would with these absolute values range within US\$0.07-0.24 per ton of carbon dioxide during a 10 year period, or a total of US $\$ 49$ million. Given temporary CCX prices, thus would marginally shift up the emission abatement cost curve in Figure 8, so that cost-effectiveness in terms of deforestation avoided would be reduced by roughly $3 \%$.

This addresses the transaction costs of buyers or intermediaries, but what about service providers? Poor transport infrastructure (e.g. in Amazonas' remote areas) can potentially drive up their transaction costs in negotiating contracts and cash in payments. REDD initiatives might learn important lessons from other experiences with decentralized conditional cash transfers, such as the Brazilian Family Assistance Program (Bolsa Familia) (Hall 2006).

\section{THE POLITICAL ECONOMY OF REDD}

The Amazon framework conditions for REDD described in Section 1 also have implications in terms of:

1. Who may be the winners and the losers?

2. Which areas become eligible for REDD?

3. What share of the REDD potential can be considered truly additional

First, REDD will only attract large-scale investments, if additional emission reductions can be credibly demonstrated. For a region with highly unequal land and power distribution like the Brazilian Amazon, smallholders and forest-dwelling communities may not be the prime beneficiaries when additionality is put at the forefront. Chomitz (2006) shows that less than $20 \%$ of forest clearings in the Amazon are smallscale, i.e. smaller than 20 ha, though with some differences between Amazon regions (populist vs corporative frontiers). To the extent that it is necessary to compensate those who would benefit from (legal) deforestation, and thus would suffer the opportunity costs, a rather high share would need to go to commercial farmers at medium and large scales. On the other hand, for a REDD programme to be politically acceptable in Brazil, and to avoid significant leakage to the smallholder sector, it may turn out to be beneficial to invest a more than threat-proportional share of REDD money into rewarding good forest stewards and local communities for assistance in monitoring protected areas. A general sense of fairness will be crucial for the political acceptance of REDD, both in ES buyer and seller countries.

An example may underscore this point. The Forest
Valuation Pact, a recently proposed scheme to compensate farmers for not deforesting with primarily Treasury resources, received mixed political reactions. It was criticised that services to the benefit of the global society should be paid for by Brazilian taxpayers, especially when the beneficiaries would be large commercial landowners with a history of aggressive land clearing (such as in Mato Grosso) - i.e. rewarding the bad rather than the good guys. However, it is possible that political acceptance of such compensations would be higher if funding came directly from international carbon markets, rather than from the Brazilian state that cannot focus solely on additionality while closing its eyes to social objectives.

Second, only some of the highly threatened forests in the Brazilian Amazon can potentially be protected through direct REDD payments, because much of the land cleared is public or has insecure tenure. Direct payments to farmers on land with deficient access control will be inefficient - and paying land grabbers to desist from invasions would likely create outright perverse incentives for others to simulate similar clearing threats in order to claim compensations. As for the large protected areas and indigenous territories, many lie in remote and relatively undisturbed areas where de facto threats are low, and payments here could easily become "hot air". Deforestation within protected areas has been relatively low, compared to outside (see Ferreira et al. 2005 for a comparison of deforested areas in and outside protected areas), though part of this may be explained by remoteness rather than protection status. Studies of less remote protected areas in the state of Pará show that illegal deforestation there can get close to regional averages (Velásquez et al. 2006). Yet, from a legal point of view, paying REDD in these areas based on opportunity costs is highly questionable. At best, one could imagine the use of REDD to co-finance the creation of new protected areas, or subsidize recurrent costs in ways that clearly diminish threats to standing forests as carbon stocks.

Third, in the opportunity cost estimation it was assumed that all privately owned forests are potentially available for REDD. Yet as mentioned, Brazilian forest retention standards require $50-80 \%$ of private property in the Amazon region to remain under forest. Although few farmers de facto comply with this requirement, REDD in these areas would legally not be additional. Conversely, restricting payments exclusively to legally convertible forests on private properties would dramatically reduce the scope for REDD. Some combination of improved command-and-control tools and incentives is probably necessary.

Finally, a similar efficiency vs. fairness trade-off can obviously apply at the level of distinctive federal states within Brazil. Above it was found that the currently competitive REDD options for the environmentally pro-active Amazonas state were summing up to US\$123 million, buying out $92 \%$ of deforestation, while for the Mato Grosso state with a history of aggressive agricultural expansion the figure was nine times that high ( US\$1.1 billion), buying out less than half $(47 \%)$ of forest clearing. In other words, if funds were allocated exclusively according to additionality criteria, 
Mato Grosso could skim the bulk of REDD payments and still continue with high-value forest clearing for its economic development, while Amazonas would have to do with much less transfers and simultaneously be almost barred from further land clearing. This disparity results from agricultural market dynamics and the basic economics of deforestation, but also in part because Amazonas state had in advance declared many more protected areas than Mato Grosso. If the REDD system is operated at the level of the federal government in Brasilia, the distribution of resources on federal states should surely be guided largely by additionality concerns, but must also make rewards for 'good past stewardship' (e.g. through co-financing for national parks, reserves, etc.). Otherwise, a backlash against these environmentally progressive policies could occur, which would also negatively impact on the protection of carbon stocks.

\section{CONCLUSIONS}

The empirical assessment of likely REDD opportunity costs in the Brazilian states of Amazonas and Mato Grosso, based on Brazil's official agricultural statistics, clearly supports previous claims that REDD can be a cost-effective way of reducing deforestation in the Brazilian Amazon. This conclusion is valid in the market-remote Amazonas state with its conservationist policies and low deforestation rates, but equally so in the agribusiness-oriented Mato Grosso state with its vibrant soy and beef industries and a history of aggressive forest clearing. A partial assessment of approximate transaction costs does not seem to alter this fundamental conclusion: at current carbon prices, paying for protecting forests is a good deal with wide options.

Nonetheless, the comparison of the two very different federal states in the Amazon also shows that (at current carbon prices and demand) zero deforestation is an unrealistic goal to be achieved through REDD: some high-value uses of converted land cannot be "bought out" through REDD. In addition, only a minor share of deforestation happens on lands with private secure tenure, or at the least with effective control over third-party access rights. Direct REDD payments can therefore not be a substitute for improved commandand-control policies in the Amazon region - in fact, REDD could also co-finance this improvement. Yet, direct REDD payments can be a meaningful complementary strategy, providing positive economic incentives, i.e. "carrots" that will help increasing the political acceptability of "stick" policies to effectively reduce deforestation.

At current carbon prices, how much deforestation would REDD really reduce, and at what costs? The answer from above was "almost all deforestation in Amazonas (525094 ha), and half to two thirds in Mato Grosso's SLAPR areas (554 842 ha), at somewhere between US\$330 million and US\$1 billion of total costs" - depending on the payment modality (uniform rates vs. differentiated cost-aligned compensations) and whether permanent or transitory CCX carbon prices (the latter implying a $39 \%$ price discount) apply. Taking the two states together this corresponds to roughly 360 million tons of reduced carbon emissions in a ten year period.

Nevertheless, it has to be kept in mind that only about a quarter of private land in Mato Grosso is licensed under SLAPR. If one makes the heroic assumption that SLAPRregistered farms are fully cost-representative of all farms in Mato Grosso, one would have to multiply SLAPR cost estimates by four. This would raise to somewhere between US\$1.2 and US\$4 billion - again depending on the assumptions about payment modes and carbon prices. This large variance of estimates points to the importance of designing the payment mechanism in a way that combines cost effectiveness with equity considerations.

\section{DISCUSSION AND POLICY PERSPECTIVES}

How do the presented results compare to other REDD opportunity cost studies? Nepstad et al. (2007) estimated potential productivity of beef and soybean production based on suitability of climate and soil conditions and at spatially more disaggregated scales than ours. Their emission abatement cost curve does therefore include very high-cost abatement options at its upper end. Including all, not only private, land plus the use of a $5 \%$, instead of $10 \%$, discount rate and a 30 , instead of 10 , year time period for cost accounting boosts their estimate of total opportunity costs to over US\$200 billion for the whole Brazilian Amazon. Because they include not directly threatened, but potentially suitable, forests, the carbon unit-cost estimates in the Nepstad et al. study are not directly comparable with the values presented here. Nevertheless, the authors share the conclusion that REDD in the Amazon is a highly competitive mitigation option at current carbon prices.

Swallow et al. (2007) estimated emission abatement cost for sites in the Peruvian Amazon. Their approach is based on cost-benefit analyses of existing land-use systems and observed land-use changes. The study presents values that correspond to this study's findings for the state of Amazonas, where more than $90 \%$ of emission reductions are competitive at current carbon prices. At a $10 \%$ discount rate Swallow et $a l$. estimate that the majority of carbon emitting land use changes between 1998 and 2007 could be compensated for at less than $\mathrm{US} \$ 5 / \mathrm{tCO}_{2}$.

This study's approach to estimating opportunity costs of REDD in Mato Grosso and Amazonas required the following key assumptions:

1. Deforestation on private land is equal to the municipal level deforestation rate. This potentially underestimates true total opportunity costs, because private deforestation rates are expected to be higher than those in protected areas or public land. Preliminary results from the Brazilian Agricultural Census 2006, for instance, suggest that forest on private lands in Mato Grosso between 1995 and 2006 has been reduced at an average annual rate of $5 \%$, i.e. about twice the 2000-2006 rate at the state level. 
2. REDD-compatible benefits from the standing forest, e.g. extraction of non-timber forest products, are zero. This assumption leads to a potential overestimation of per ha opportunity costs. For the type of farmers that most contribute to deforestation in the Amazon (i.e. commercial cattle and agricultural producers), it is expected that non-timber forest products play a minor role in resource use decisions.

3. Current municipal land-use distribution and profits are fully replicated on deforested land. The direction of bias introduced by this rigid assumption is ambiguous, and depends on the relative weight of new opportunities (e.g. technological progress, price changes, new crops such as biofuels) versus incremental limitations (e.g. running into soil fertility or producer capital constraints).

Deforestation rates on private land, the actual net returns to individual land uses, and the carbon content of forests can all be expected to vary much across the Amazon. The upcoming Brazilian agricultural census will provide more solid data for illuminating the first two factors. Other changes in assumptions could also influence the results. Differentiation of returns for cattle-based activities, i.e. ranching vs dairy farming and land-intensive/ modernized versus landextensive/ rudimentary operations could reveal more land units at the high-cost end. A more detailed assessment of transport costs would likely reduce the opportunity costs for remote land units (of which there are many in the state of Amazonas) and bulky commodities.

Given favourable opportunity costs for REDD, it might be beneficial to separate the carbon-supply for the "deforestation" and "forest degradation" elements. One pathway is to offer payments for reduced-impact logging that minimizes carbon losses. A second would be a "log-andprotect" strategy of extracting only the most valuable timbers and then setting aside the resulting secondary forests for strict conservation. A full assessment of the cost-effectiveness of REDD, however, needed to account for losses incurred throughout the entire value chain of agricultural production in the Amazon. As a result, governments might decide to tax income from private REDD agreements to make up for losses in productive activity, which would further increase total costs.

Second, the above observed difficulty of precisely estimating highly variable opportunity costs in space might be alleviated through the use of more sophisticated economic techniques. This study's results suggest price differentiation between REDD suppliers can make REDD considerably cheaper (see Senario I and II in table 3). Experiments with inverse auction systems where producers 'self-reveal' their costs and preferences have progressed sufficiently to also pilot these techniques in the Amazon, thus validating ex-ante cost estimates and avoiding over- or underpaying individual farmers due to aggregation errors.

Third, who would pay for REDD on a massive scale, and at what price? Only some markets currently accept REDD carbon. With roughly $47 \mathrm{Mt} \mathrm{CO}_{2} / \mathrm{yr}$ (available at current CCX prices) from private lands in Amazonas and Mato Grosso being thrown into the world market, the above assumed constant prices on existing voluntary markets might in fact drop significantly, unless there is a simultaneous hike in demand.

Finally, the REDD scenario on which the presented calculations are based would only pay for those private land areas that will be deforested. However, it is illusionary to predict exactly where deforestation is bound to happen. Furthermore, even if this was possible, paying only for threatened areas will relocate part of conversion pressures to areas not covered (leakage). To counteract the inevitable imprecision of spatial predictions and leakage, payment schemes may need to have a broader spatial coverage of all private areas potentially at risk, and/or raise the carbon stocks set aside as 'insurance reserve'. This will make REDD schemes more expensive than suggested above.

\section{ACKNOWLEDGEMENTS}

Technical and financial support from the following institutions is gratefully acknowledged: Embrapa Amazonia Oriental (GIS Laboratory), Sustainable Development Secretariat (SDS) of the State of Amazonas, Instituto Centro de Vida (ICV in Mato Grosso), Zentrum für Internationale Migration und Entwicklung (CIM), and the European Union.

\section{REFERENCES}

ANDERSEN, L. E., GRANGER C. W. J., E. J. REIS, D. WEINHOLD, and S. WUNDER. 2002. The dynamics of deforestation in the Brazilian Amazon. Cambridge University Press, Cambridge, UK.

ADA 2002. Diagnóstico e cenarização macrossocial da Amazônia Legal: Estrutura fundiária na Amazônia Legal - 1950/1995, Belém.

BARRETO, P., AMARAL, P., VIDAL, E., and UHL, C. 1998. Costs and benefits of forest management for timber production in eastern Amazonia. Forest Ecology and Management, 108: 9-26.

BÖRNER, J., MENDOZA, A., and VOSTI, S.A. 2007. Ecosystem services, agriculture, and rural poverty in the Eastern Brazilian Amazon: Interrelationships and policy prescriptions. Ecological Economics, 64: 356-373.

CACHO, O., MARSHALL, G.R., and MILNE, M. 2005. Transaction and abatement costs of carbon-sink projects in developing countries. Environment and Development Economics, 10, 597-614.

CATTANEO, A. 2002. Balancing agricultural development and deforestation in the Brazilian Amazon. International Food and Policy Research Institute (IFPRI), Washington D.C.

CHOMITZ, K.M. 2006. At Loggerheads? Agricultural expansion, poverty reduction, and environment in the topical forests. World Bank, Washington D.C.

CHOMITZ, K.M. and THOMAS, T.S. 2001. Geographic 
patterns of land lse and land intensity in the Brazilian Amazon. Development Research Group, The World Bank, Washington D.C.

DUTSCHKE, M. and SCHLAMADINGER, B. .2003. Practical issues concerning temporary carbon credits in the CDM. In HWWA - Diskussionspapier Nr. 227.

FEARNSIDE, P.M. 2003. Deforestation control in Mato Grosso: A new model for slowing the loss of Brazil's Amazon forest. Ambio, 32.

FERREIRA, L.V., VENTICINQUE, E., and ALMEIDA, S. 2005. O desmatamento na Amazônia e a importância das áreas protegidas. Estudos Avançados, 19.

FNP 2007. AGRIANUAL. FNP Consultoria e Comercio, São Paulo, Brazil.

GOVERNMENT OF AMAZONAS 2007. Amazonas Initiative on Climate Change, Forest Conservation, and Sustainable Development. Government of Amazonas, Manaus, Brazil.

GRIEG-GRAN, M. 2006. The cost of avoiding deforestation. Report prepared for the Stern Review of the Economics of Climate Change. International Institute for Environment and Development (IIED), London.

HALL, A. 2006. From Fome Zero to Bolsa Família: Social policies and poverty alleviation under Lula. Journal of Latin American Studies, 38, 689-709.

HOUGHTON, R.A., LAWRENCE, K.T., HACKLER, J.L., and BROWN, S. 2001. The spatial distribution of forest biomass in the Brazilian Amazon: a comparison of estimates. Global Change Biology, 7, 731-746.

IBGE (1995/6) Censo Agropecuário Instituto Brasileiro de Geografia e Estatística (IBGE).

IPCC (2007). Forth Assessment Report: Summary for policy makers. Intergovernmental Panel on Climate Change.

MARGULIS, S. 2004. Causes of Deforestation of the Brazilian Amazon. World Bank, Washington D.C.

MAY, P.H., BOYD, E., VEIGA, F., and CHANG, M. 2003. Local sustainable development effects of forest carbon projects in Brazil and Bolivia. IIED Catalogue.

MILNE, M. 1999. Transaction costs of forest carbon projects. Centre for International Forestry Research (CIFOR) Bogor, Indonesia.

MORTON, D.C., DEFRIES, R.S., SHIMABUKURO, Y.E., ANDERSON, L.O., ARAI, E., DEL BON ESPIRITOSANTO, F., FREITAS, R., and MORISETTE, J. 2006. Cropland expansion changes deforestation dynamics in the southern Brazilian Amazon. Proceedings of the National Academy of Sciences of the United States of America, 103, 14637-14641.

NEPSTAD, D., SOARES-FILHO, B.S., MERRY, F., MOUTINHO, P., RODRIGUES, H.O., BOWMAN, M., SCHWARTZMAN, S., ALMEIDA, O., and RIVERO, S. 2007. The costs and benefits of reducing carbon emissions from deforestation and forest degradation in the Brazilian Amazon. WHRC, IPAM, UFMG, Report presented at the COP13, Bali, Indonesia.

POKORNY, B. and STEINBRENNER, M. 2005. Collaborative monitoring of production and costs of timber harvest operations in the Brazilian Amazon.
Ecology and Society, 10.

SAATCHI, S.S., HOUGHTON, R.A., DOS SANTOS ALVALA, R.C., SOARES, J.V., and YU, Y. 2007. Distribution of aboveground live biomass in the Amazon basin. Global Change Biology, 13: 816-837.

SOARES-FILHO, B.S., NEPSTAD, D.C., CURRAN, L.M., CERQUEIRA, G.C., GARCIA, R.A., RAMOS, C.A., VOLL, E., MCDONALD, A., LEFEBVRE, P., and SCHLESINGER, P. 2006. Modelling conservation in the Amazon basin. Nature, 440, 520-523.

STERN, N. 2007. The Economics of Climate Change. The Stern Review Cambridge University Press, New York.

SWALLOW, B., NOORDWIJK, M.V., DEWI, S., MURDIYARSO, D., WHITE, D., GOCKOWSKI, J., HYMAN, G., BUDIDARSONO, S., ROBIGLIO, V., MEADU, V., EKADINATA, A., AGUS, F., HAIRIAH, K., MBILE, P., SONWA, D., and WEISE, D. 2007. Opportunities for avoided deforestation with sustainable benefits. An Interim Report by the ASB Partnership for the Tropical Forest Margins, Nairobi, Kenya.

TONI, F. 2006. Gestão Florestal na Amazônia Brasileira: Avanços e obstáculos em um sistema federalista. CIFOR/ CIID/IDRC.

VELÁSQUEZ, C., VILLAS BOAS, A., and SCHWARTZMAN, S. 2006. A challenge for integrated environmental management in agricultural frontier territory in western Pará, Brazil. Revista de Administração Pública, 40.

VOSTI, S.A., WITCOVER, J., and CARPENTIER, C.L. 2002. Agricultural intensification by smallholders in the western Amazon: From Deforestation to sustainable land use, Washington D.C.

WUNDER, S., and ALBÁN, M. 2007. Decentralized payments for environmental services: the cases of Pimampiro and PROFAFOR in Ecuador. Special Issue of Ecological Economics (accepted - available online). 